\title{
Consolidation of the number of treasury shares: The South African experience
}

\author{
M. Vermeulen* \\ School of Accountancy, University of Stellenbosch \\ Private Bag X1, Stellenbosch, 7600, South Africa, \\ vrmeulen@sun.ac.za \\ Y. Yaffar \\ University of Stellenbosch Business School \\ P O Box 610, Bellville, 7535, South Africa
}

\begin{abstract}
Unlike most other values found in companies' annual reports, there are no accounting standards that prescribe the calculation of market capitalisation and net asset value per share. These two figures play quite a significant role when valuing and comparing different companies. It is also frequently used in determining when a company should repurchase its own shares. In South Africa the number of the holding company's shares can differ from the total number of the group's shares after consolidation, as subsidiaries and share trusts are allowed to hold shares in their holding company. The published financial statements of a sample of JSE-listed companies were investigated to determine which number of shares companies use to calculate net asset value per share and market capitalisation, and if it is used consistently. Eight different combinations of consolidated and unconsolidated numbers of shares were found in the calculations of market capitalisation and net asset value per share showing inconsistency in application across the JSE-listed companies.
\end{abstract}

\begin{abstract}
Key words
Net asset value per share; Market capitalisation; Group shares (consolidated number of shares); Company shares (unconsolidated number of shares)
\end{abstract}

*To whom all correspondence should be addressed.

\section{Introduction}

Share repurchases have increased in popularity in South Africa since it was first allowed in 1999. Motivations for repurchasing shares include adjustments to capital structures, distributing excess cash, substituting cash dividends, defence against takeovers and signalling. All these reasons have merit, however, signalling has emerged from the literature as one of the most popular explanations (Vermaelen, 1981; Constantinides \& Grundy, 1989; Baker, Powell \& Veit, 2003). Managers have the necessary information available regarding the value of their company, and any announcement concerning share transactions is considered a valuable signal to the less informed market.

Managers often drive a repurchase of their company's shares because they are undervalued, claiming their companies' own shares are 'good investments' (Baker, Gallagher \& Morgan, 1981; Wansley, Lane \& Sarkar, 1989). A survey of 642 top financial executives by Baker $e t$ al. (2003) revealed that the most highly cited reason for share repurchases is signalling, more specifically of the fact that managers believe their company is undervalued. In an efficient market, prices should adjust immediately after the share repurchase is announced, and the new equilibrium price is supposed to reflect the true value of the company (Ikenberry, Lakonishok \& Vermaelen, 1995).
Ikenberry et al. (1995) examined the long-run performance of shares following open market repurchase announcements. They found that the average above normal four-year buyand-hold return after the initial announcement for value shares to be $45.3 \%$. Value shares are undervalued shares, i.e. those shares for which the share price is below the value of the share, measured by Ikenberry et al. (1995) as the bookto-market ratio. This ratio compares the book value to the market value of the company. They found that undervaluation will more likely drive share repurchases in companies with higher book-to-market ratios. So to determine if a company is undervalued, and share repurchases should be undertaken, the book value (i.e. net asset value per share) should be determined.

The concept of net asset value per share in the context of share repurchases is a very important concept. According to the theory, shares should rather be repurchased when they are undervalued, as this will lead to an upward adjustment of the share price, and correct the under pricing. The method of calculating net asset value per share is therefore essential to the manager making the decision about when to repurchase shares.

To calculate net asset value per share, the total net assets (or equity) of the company is divided by the number of issued shares. In the United Kingdom (UK) companies are allowed 
to repurchase their own shares and keep them as treasury shares. These treasury shares are deducted from the company's issued share capital. Subsidiaries and share trusts, however, are not allowed to acquire shares in their holding companies (Bhana, 2006). Thus the number of issued shares will be the same for the holding company as for the consolidated group.

In South Africa, however, shares that are repurchased by the company itself must be cancelled and restored to authorised, unissued capital. Subsidiaries and share trusts are allowed to purchase shares in their holding companies (which is seen as a repurchase transaction from a group point of view), and these shares are referred to as treasury shares. The treasury shares should be deducted from issued share capital when consolidating financial statements.

Both South Africa and the UK apply International Financial Reporting Standards (IFRS) for accounting purposes. IFRS are issued by the International Accounting Standards Board (IASB), situated in the UK. A problem arises in that the same accounting standards apply to both countries, but the legal framework is completely different. The standards issued by the IASB have no specific requirements for the disclosure and reconciliation of treasury shares with the group share numbers, owing to the fact that in the UK there can be no difference between the holding company's and group's number of shares. In the UK treasury shares can only refer to shares held by the company, which are deducted from the holding company's (and therefore automatically the group's) issued capital. In South Africa, however, treasury shares refer to shares held by subsidiaries and trusts, and should be deducted from the issued capital of the group only, creating a difference between the number of shares issued for the holding company and the group.

The number of issued shares is used in a number of calculations measuring an entity's performance, such as earnings per share, market capitalisation and net asset value per share. Since there can be no difference between the company and group number of shares in the UK, there has been no need for an accounting standard that prescribes which number of shares should be used in the calculation of net asset value per share or the calculation of market capitalisation. The only standard that does refer to the number of shares is IAS 33 (IASB, 2011c), which prescribes that the consolidated number of shares be used when calculating earnings per share of a group.

This now raises two questions: When determining if a South African company's shares are undervalued, which number of shares should be used when calculating net asset value per share - the number of company shares, or the number of group shares? Further, which number of shares should be used when calculating market capitalisation?

\section{Literature review}

\section{Reporting requirements}

In South Africa, three types of entities in a group are allowed to purchase shares in the holding company in terms of The Companies Amendment Act, No. 37 of 1999, being the holding company itself, its subsidiaries and its shares trusts (RSA, 1999). Shares repurchased by the holding company must be cancelled (Section 85(8)), and the number of issued shares of the holding company are therefore reduced, whereas the number of treasury shares are not cancelled (Section 89). In countries where subsidiaries and trusts are not allowed to purchase shares in their holding companies, the number of holding company shares and the number of group shares in the consolidated statements are identical. In South Africa, however, owing to the fact that subsidiaries and trusts are allowed to purchase shares in their holding companies, the number of group shares can be less than the number of company shares as a result of the consolidation principle.

The disclosure requirements on share repurchases in the annual report is prescribed by two International Financial Reporting Standards (IFRS). The first Standard is IAS 1 Presentation of Financial Statements (IASB, 2011a). IAS 1 requires an entity to disclose, either in the statement of financial position or the statement of changes in equity or in the notes, a reconciliation of the number of shares outstanding at the beginning and end of each period. This Standard does not make it clear whether it refers to the number of company shares, number of group shares or both. IAS 1 also requires the disclosure of shares that are held by the entity, its subsidiaries or associates (i.e. treasury shares). It is not clear whether the reconciliation of opening and closing balances also applies to treasury shares.

The second Standard is IAS 32 Financial instruments: Presentation (IASB, 2011b). IAS 32 requires that shares repurchased by entities in the group should be deducted from equity in the group's annual financial statements. Deduction of the rand amounts spent on treasury shares is in line with consolidation principles followed in the group annual report. One could deduce that the same consolidation principles should be applied to the number of treasury shares. However, IAS 32 is not explicit when it refers to the deduction from equity. The question thus arises, does IAS 32 refer only to the rand amount of treasury shares or does it imply that the 'deduction' should also refer to the number of shares and thus create a difference between the number of company shares and the number of group shares?

As a result of the uncertainty regarding the disclosure of the number of company, treasury and group shares, many companies in South Africa do not provide a reconciliation of the movement in treasury shares, and do not publish the consolidated number of shares of the group, making it very difficult to do research in this area. 


\section{Related South African research on share repurchases}

In an article by Bester, Hamman, Brummer, Wesson and Steyn-Bruwer (2008), it was found that only about $25 \%$ of companies that published market capitalisation in their 2006 annual report and participated in share repurchases since 1 July 1999, based their market capitalisation on the number of group shares. The other $75 \%$ of the companies did not deduct subsidiary and/or trust repurchases, and calculated their market capitalisation based on the number of company shares. Reference was also made to the fact that the daily market capitalisation as published by the JSE for listed companies ignores all treasury shares (the same method employed by the above-mentioned $75 \%$ of companies).

Wesson and Hamman (2011) discovered that companies listed on the JSE interpret the disclosure requirements in IAS 1 en IAS 32 very differently. The number of group shares is not disclosed consistently. Companies also do not disclose treasury shares consistently, and often do not give a reconciliation of the opening and closing balance, making it difficult to determine the number of group shares in financial statements where it is not disclosed (Wesson \& Hamman, 2011; Bester et al., 2008).

It is clear that the research on repurchases and treasury shares in South Africa is extremely limited, and even more so when the focus is only on the number of shares.

\section{Which number of shares to use?}

For performance measurement purposes the number of shares will be important in at least three cases, namely:

1. to determine the weighted average number of shares when calculating earnings per share and headline earnings per share (according to IAS 33)(IASB, 2011c);

2. when calculating net asset value per share = equity / number of shares; and

3. when calculating market capitalisation $=$ number of shares $\mathrm{x}$ price per share.

IAS 33 (IASB, 2011c) prescribes that earnings per share as well as headline earnings per share must be based upon the weighted average number of shares after the weighted number of treasury shares has been deducted. For the purposes of calculating earnings per share and headline earnings per share, the accounting standards are very explicit: the weighted average number of group shares, and not the weighted number of company shares, must be used as the denominator.

However, no accounting standard exists for the calculation of net asset value per share (Hattingh, 2012). If, however, earnings per share should be based on the number of group shares, it would be fair to say that net asset value per share should also be based on the number of group shares, since both are measures of the value of the group of companies.
Earnings per share measures the earnings attributable to each shareholder for the year, which should be reflected in the net asset value per share attributable to each shareholder (a measure of cumulative earnings over time) at the end of the current year. The authors' view is therefore that the group number of shares (consolidated) should be used when calculating net asset value per share.

Market capitalisation measures the value of a company in terms of its tradable shares. It is seen as an indication of the public opinion of a company's net worth and is used often when valuing and comparing different shares. As it is an important piece of information in the investment arena, it makes sense that it should be calculated on a consistent basis between companies. Bester et al. (2008), however, found that the majority of JSE-listed companies use the company number of shares (unconsolidated), but there are quite a few companies that use the group number of shares (consolidated). The authors' view is that the group number of shares (consolidated) should be used, as market capitalisation is also an indication of the value of the group. Shares that are held by members of the group are deducted when calculating equity of the group, and the same principle should be applied when calculating the market value of this equity.

\section{Research problem and objectives}

According to Ikenberry et al. (1995) shares should be repurchased when they are undervalued, but that can only be determined using net asset value per share. Both net asset value per share and market capitalisation figures are also used by investors when valuing companies, and one would therefore expect that there are standard methods for calculating these values. The aim of this study is to determine which number of shares JSE-listed companies use to calculate market capitalisation and net asset value per share, and whether they use the same number consistently. If it is not consistent, guidelines might be needed to ensure that these figures are comparable between different companies.

\section{Research methodology and collection of data}

As discussed above, there are no standards that prescribe the calculation or disclosure of market capitalisation and net asset value per share. The disclosure of market capitalisation is optional, but the disclosure of net asset value per share is required by section 3 and 8 of the JSE Listing Requirements (JSE, 2010). Even with the JSE requiring the disclosure of net asset value per share, it gives no guidelines for the calculation of this figure.

As a result of the fact that it is optional, not all companies publish market capitalisation. A sample of 75 companies was therefore selected from companies that have published both market capitalisation and net asset value per share (or tangible net asset value per share) in their 2009 annual reports. It is a non-random sample, so as to include as many companies as possible. Only the 2009 annual reports were 
used, as companies generally calculate these figures on a consistent basis from year to year.

Annual reports were obtained as hard copies from the companies themselves, or downloaded either from the McGregor BFA database (Product called: Library) or from individual companies' websites. The following information was captured from the annual reports for each company exactly as it was published at the 2009 financial year end:

- Number of issued shares of the holding company (unconsolidated)

- $\quad$ Number of shares held by subsidiaries (treasury)

- Number of shares held by share trusts (treasury)

- $\quad$ Number of issued shares of the group (consolidated) ${ }^{1}$

- Monetary value of equity (from statement of financial position)

- $\quad$ Share price at year end (from statistical reviews)

- Market capitalisation (from statistical reviews)

- Net asset value or tangible net asset value per share (from statistical reviews)

Each company's market capitalisation and net asset value per share was recalculated using the consolidated as well as the unconsolidated number of shares and compared to the number that was published. This process determined which number of shares was used by each company in calculating market capitalisation and net asset value per share.

\section{Challenges encountered when collection data}

Some companies publish definitions of how market capitalisation and net asset value per share and/or tangible net asset value per share is calculated. However, a large number of companies do not supply such definitions. In a number of cases the definitions were not very explicit, for example, "shares in issue" is not an obvious concept. It could refer to the number of company shares or the number of group shares. In all cases the first step was to calculate net asset value per share by dividing equity by both the number of company and group shares to determine which denominator was used. If the calculated net asset value per share did not tally with the printed net asset value per share, then attention was directed to the definition of the numerator (equity) that was used. Some companies included minority interest in the numerator (equity), while some companies also included preference share capital in the numerator. Determining which definition of equity was used became a case of trial and error.

Another problem encountered was where a company had listed as well as unlisted equity instruments. The rand amounts of both instruments are included in the numerator (equity) of net asset value per share. It does therefore make sense that both instruments should be used in determining the denominator (number of shares) of net asset value per share. When deciding whether a company is undervalued or

\footnotetext{
${ }^{1}$ Out of the 75 companies in the sample, 30 did not publish this number. In these cases it was recalculated by the authors.
}

overvalued, however, the comparison is made between net asset value per share and the market price (Ikenberry et al., 1995) and net asset value per share should therefore be comparable to the market price. The market price, however, only refers to the listed equity instrument.

The example of Remgro could perhaps assist in highlighting the problem in practice. In 2009 Remgro had 439479751 listed ordinary shares of one cent each (R4 395 million) as well as 35506352 unlisted B ordinary shares of 10 cents each (R3 551 million), resulting in a total of 474986103 shares issued by the company. Remgro had 3500000 treasury shares in 2009, thus resulting in 471486103 group shares. Total equity amounted to R38 072 million and included the R4 395 million as well as the R3 551 million. Remgro calculated net asset value per share as R38 072 million divided by 471486103 group shares resulting in R80.75 per share. This net asset value per share includes the value of the unlisted B ordinary shares, but the market value of R67.50 only refers to the listed ordinary shares.

To enable a calculation of equity only for the listed ordinary shares, R3 551 million could be deducted from R38 072 million to obtain a "pure" listed equity. But then reserves must also be split between reserves contributed by the listed ordinary shares and that contributed by the unlisted B shares. This latter split is not feasible. In terms of the definition of a value share (Ikenberry et al., 1995), Remgro might be undervalued.

Quite often separate notes were given for share capital (of the holding company) and treasury shares, with no indication of the number of group shares. In such cases, the number of group shares was calculated and compared to the weighted average number of shares and/or the details of the non-public shareholders in the so-called shareholder spread (as prescribed by the JSE Listing Requirements) to confirm the number of group shares as calculated by the authors.

For the above-mentioned reason it was decided to write letters to each company that did not use the consolidated number of shares for market capitalisation and net asset value per share. The first letter was addressed to the company secretary and a subsequent letter to the financial director. Included in this correspondence to each company were the authors' detailed calculations of that company's net asset value per share and market capitalisation, showing how these compared with the figures published in its financial statements. The authors' view on the matter (that the consolidated number of shares should be used for both market capitalisation and net asset value per share) was explained, and the company secretary and financial director were asked to comment on the calculations and give their opinion on which number of shares should be used for each calculation. An example of the letter appears in Appendix A.

\section{Results}

Table 1 lists the number of shares used by each company in its calculation of market capitalisation and net asset value 
per share. Five companies of the original sample of 75 are not included in Table 1. They are Capitec Bank Holdings Ltd, Kap International Holdings Ltd, MTN Group Ltd, The Spar Group Ltd and Universal Industries Corporation Ltd. These companies did not have any subsidiaries or share trusts that were consolidated in 2009, and therefore the market capitalisation and net asset value per share figures are calculated correctly by default. Where the number of shares is indicated as 'unknown' in Table 1, it was impossible to recalculate the market capitalisation or net asset value per share with the information provided in the financial statements.

Table 1: Summary of number of shares used for market capitalisation (MC) and net asset value per share (NAV)

\begin{tabular}{|c|c|c|c|c|c|c|c|c|}
\hline & \multicolumn{4}{|c|}{ Market capitalisation } & \multicolumn{4}{|c|}{ Net asset value per share } \\
\hline & Group & $\begin{array}{c}\text { Group } \\
\text { (only sub) }\end{array}$ & Company & Unknown & Group & $\begin{array}{c}\text { Group } \\
\text { (only sub) }\end{array}$ & Company & Unknown \\
\hline Group - both & 17 & & & & 17 & & & \\
\hline Company \& group & & & 37 & & 37 & & & \\
\hline Company - both & & & 8 & & & & 8 & \\
\hline Company \& unknown & & & 3 & & & & & 3 \\
\hline Unknown \& group & & & & 2 & 2 & & & \\
\hline Unknown \& company & & & & 1 & & & 1 & \\
\hline Incorrect group (MC) & & 1 & & & 1 & & & \\
\hline Incorrect group (NAV) & & & 1 & & & 1 & & \\
\hline Total & 17 & 1 & 49 & 3 & 57 & 1 & 9 & 3 \\
\hline
\end{tabular}

The majority of companies (37) used the consolidated number of shares in their calculation of net asset value per share, but used the unconsolidated number of shares when they calculated market capitalisation. Seventeen companies used the consolidated number of shares for both calculations, whereas eight companies used the unconsolidated number of shares for both calculations.

Two companies used a consolidated number of shares for market capitalisation and net asset value per share respectively, but they only consolidated the share trusts of their subsidiaries and not their own. The remaining six companies used an unknown number of shares for either market capitalisation (3) or net asset value per share (3).

In total, 17 companies used the consolidated number of shares in the calculation of market capitalisation, compared to the 57 companies that used the consolidated number of shares in the calculation of net asset value per share. See Appendix B for more detail on which companies used which number of shares. From the sample of 75 companies, three companies were identified that published two figures for market capitalisation - using the consolidated as well as unconsolidated number of shares.

The differences in market capitalisation based on the consolidated and unconsolidated number of shares was calculated for those companies that used the unconsolidated number instead of the consolidated number. The results are shown in Appendix C. The average increase in market capitalisation is $8.56 \%$, with the differences ranging between $0.06 \%$ and $42.81 \%$. The percentage increase was calculated as the difference in market capitalisation, divided by market capitalisation based on the consolidated number of shares. The same was done for companies that used the unconsolidated number of shares instead of the consolidated number for the calculation of net asset value per share. The results are shown in Appendix D. The average decrease in net asset value per share is $3.67 \%$, with the differences ranging between $0.05 \%$ and $17.1 \%$.

From the letters that were sent out to financial directors, responses were received from only 17 . Their responses are summarised in Table 2 below.

Table 2: Reasons for using specific number of shares

\begin{tabular}{l|c}
\hline Market capitalisation & $\begin{array}{c}\text { Number of } \\
\text { companies }\end{array}$ \\
\hline Reasons for using unconsolidated number of & 4 \\
\hline Conform to JSE publications & 3 \\
\hline Standard practice in financial markets & 2 \\
\hline $\begin{array}{l}\text { Total value of company is market value of all } \\
\text { issued shares }\end{array}$ & 2 \\
\hline $\begin{array}{l}\text { Treasury shares are still issued shares } \\
\text { Interpretation used by daily newspapers and } \\
\text { other media }\end{array}$ & 2 \\
\hline \begin{tabular}{l} 
Impractical to deduct treasury shares \\
\hline $\begin{array}{l}\text { Market capitalisation measures total value of } \\
\text { shares listed on the JSE }\end{array}$
\end{tabular} & 1 \\
\hline $\begin{array}{l}\text { Commonly used definition therefore no } \\
\text { confusion for users }\end{array}$ & 1 \\
\hline \begin{tabular}{l} 
Investing as shareholders in own shares \\
\hline $\begin{array}{l}\text { Dividend per share also calculated on total } \\
\text { number of listed shares }\end{array}$
\end{tabular} \\
\hline
\end{tabular}




\begin{tabular}{l|c}
\hline $\begin{array}{l}\text { Consolidated number of shares not available to } \\
\text { investors on continuous basis }\end{array}$ & 1 \\
\hline $\begin{array}{l}\text { Use normalised basis (unconsolidated) to better } \\
\text { reflect the underlying economic and legal } \\
\text { substance of group transactions }\end{array}$ & 1 \\
\hline & \\
\hline Net asset value & \\
\hline Reasons for using unconsolidated number of \\
shares:
\end{tabular}

\section{Conclusion}

An investigation was made into the 2009 annual reports of a sample of 75 JSE-listed companies to determine what number of shares they use in the calculation of market capitalisation and net asset value per share, and if they use the same number of shares consistently. It was found that only 17 companies use the consolidated number of shares for both calculations, while 37 companies use the consolidated number of shares for calculating net asset value per share, but the unconsolidated number of shares for calculating market capitalisation. The difference may be insignificant for some companies, but for others it is substantial (even as much as a $42 \%$ increase in market capitalisation), and might influence investors' decisions.

The main reasons companies stated for using the unconsolidated number of shares when calculating market capitalisation are the following:

- The JSE uses the unconsolidated number in all their publications.

- It is standard practice in financial markets to calculate market capitalisation on the number of listed shares.

- The total value of a company is the market value of all its issued shares, irrespective of who the holders of the shares are.

The reasons given by the companies for using the unconsolidated number of shares all have merit. However, it does not make sense that companies use different methods to calculate the same figures. Comparability is one of the main qualitative characteristics that a company should strive for when preparing financial statements. It enhances the usefulness of the information presented for investors, lenders and other users when making decisions based on the information in financial statements as presented in The conceptual framework for financial reporting (IASB, 2010). Market capitalisation and net asset value per share are two items that are often used by investors to evaluate and compare different companies. Net asset value per share is also used to determine whether companies are over- or undervalued - which influences the decision to repurchase shares or not. Therefore the authors believe that these figures should be calculated in a consistent manner by all companies, i.e. based on the consolidated number of group shares. Until the International Financial Reporting Standards are adjusted to require the disclosure of market capitalisation and net asset value per share, and prescribe guidelines to calculate it, the authors propose that the JSE issue guidelines for the calculation of these figures.

\section{Further research}

After this study was completed, the new Companies Act, 71 of 2008 came into effect on 1 May 2011. According to this new act, shares that are repurchased by a company itself no longer have to be cancelled. So now, in addition to subsidiaries and share trusts holding treasury shares, the holding company itself can also hold treasury shares. It will be interesting to see what the effect thereof will be on the listed share repurchase environment in South Africa, and how companies will disclose this information.

\section{References}

Baker, H.K., Powell, G.E. \& Veit, E.T. 2003. 'Why companies use open-market repurchases: A managerial perspective', The Quarterly Review of Economics and Finance, 43:483-504.

Baker, H.K., Gallagher, P.L. \& Morgan, K.E. 1981. 'Managements' view of stock repurchase programs', Journal of Financial Research, 4(3):233-247.

Bester, P.G., Hamman, W.D., Brummer, L.M., Wesson, N. \& Steyn-Bruwer, B.W. 2008. 'Share repurchases: Which number of shares should be used by JSE-listed companies when publishing market capitalisation in annual reports?' South African Journal of Business Management, 39(4):4146.

Bhana, D. 2006. 'The company law implications of conferring a power on a subsidiary to acquire the shares in the holding company', Stellenbosch Law Review, 17(2):232250.

Constantinides, G.M. \& Grundy, B.D. 1989. 'Optimal investment with stock repurchase and financing as signals', Review of Financial Studies, 2:445-465.

Hattingh, C. 2012. 'On his high horse - Net asset value per share’, Accountancy SA, May: 13. 
Accounting Standards Board (IASB). 2010 The conceptual framework for financial reporting. London: IASB.

Accounting Standards Board (IASB). 2011a. IAS 1, Presentation of Financial Statements. London: International Accounting Standards Board (IASB).

Accounting Standards Board (IASB). 2011b. IAS 32 Financial Instruments: Presentation. London: International Accounting Standards Board (IASB).

International Accounting Standards Board (IASB). 2011c. IAS 33, Earnings per share. London: International Accounting Standards Board (IASB).

Ikenberry, D., Lakonishok, J. \& Vermaelen, T. 1995. 'Market underreaction to open market share repurchases', Journal of Financial Economics, 39(2-3):181-208.

JSE (Johannesburg Stock Exchange). 2010. 'JSE listing requirements', Service Issue no 13. [online]URL: www.jse.co.za/How-To-List/Main-Board/Listingrequirements/JSE-listing-requirements.aspx. Accessed 4 August 2011.

RSA (Republic of South Africa). 1999. The Companies Amendment Act, No. 37 of 1999. Pretoria: Government Printer.

Vermaelen, T. 1981. 'Common stock repurchases and market signalling', Journal of Financial Economics, 9:139183.

Wansley, J.W., Lane, W.R. \& Sarkar, S. 1989. 'Management's view of share repurchase and tender premiums', Financial Management, 18:97-110.

Wesson, N. \& Hamman, W.D. 2011. 'Disclosure of share capital: Are reporting standards clear?' Accountancy SA, February: 32-34. 


\title{
Appendix A
}

Date

\author{
Mr XXX \\ Financial Director \\ Company name \\ Company address \\ Johannesburg \\ 2000
}

Dear Mr XXX

Envisaged research into the methods used by companies to calculate market capitalisation and net asset value

IAS 33 requires companies to disclose earnings per share (EPS) based on the weighted number of shares issued by the group, i.e. after deducting treasury shares held by subsidiaries and trusts. No such requirements exist for the calculation of market capitalisation and net asset value (NAV) per share, but the logical assumption should be to use the same number of shares (although not weighted) as are used for EPS, since this represents the consolidated number of issued shares of the group.

A team of researchers from Stellenbosch University are preparing to conduct research into how market capitalisation and net asset value per share were calculated by a sample of 75 JSE-listed companies in the 2009 financial year, with the aim of establishing whether the number of shares used to calculate these values is that of the holding company itself

or the group. Our study will be based on data published by the selected companies in their 2009 annual reports. On completion of this study, we will submit an article on our findings and conclusions to a South African research journal for publication.

In 2008 we published a similar article in which we reported that $74 \%$ of JSE-listed companies, which had repurchased their own shares up to 2006 and had published their market capitalisation in the same year, had incorrectly calculated their market capitalisation by using the number of shares of the company, instead of the number of shares of the group (by deducting the treasury shares from the number of shares of the company). If you are interested in seeing this 2008 article, we shall gladly supply you with a copy.

Based on the results of the envisaged research, we expect to find that the bulk of our present sample of 75 companies has used the number of company shares to calculate market capitalisation, but then switched to the number of group shares to calculate NAV. 
Your company is one of the 75 companies which have been selected as part of our sample for this research. We will be grateful if you would:

- check our interpretation of your company data; and

- $\quad$ share your insights on this matter with us.
We calculated your market capitalisation and NAV (see below) for 2009 and tried to establish whether you used the number of company shares or the number of group shares (or perhaps both numbers) in your reckoning. Kindly have a look at our calculations and conclusions, and give your comments.

\begin{tabular}{|c|c|c|c|c|}
\hline \multicolumn{5}{|l|}{2009 Financial statements } \\
\hline MARKET CAPITALISATION & & & & Page number \\
\hline \multicolumn{3}{|c|}{ Number of shares held by holding company (unconsolidated): } & 718210043 & p321 \\
\hline \multicolumn{3}{|c|}{ Number of shares held by subsidiaries: } & -545111 & p177 \\
\hline Number of shares held by trust: & & & -1841664 & p177 \\
\hline \multicolumn{2}{|c|}{ Number of shares held by the group (consolidated): } & & 715823268 & \\
\hline Share price at year end (cents): & & & 12850 & p329 \\
\hline \multicolumn{5}{|l|}{ Calculated market capitalisation: } \\
\hline Based on company shares: & 718210043 & $x 12850=$ & 92289990526 & \\
\hline Based on group shares: & 715823268 & $x 12850=$ & 91983289938 & \\
\hline Published market capitalisation: & & & 92290000000 & p329 \\
\hline \multicolumn{5}{|l|}{ NET ASSET VALUE } \\
\hline Equity (ordinary shares): & & & 50547000000 & p105 \\
\hline \multicolumn{5}{|l|}{ Calculated net asset value per share: } \\
\hline Based on company shares: & 50547000000 & / $718210043=$ & 7037.91 & \\
\hline Based on group shares: & 50547000000 & / $715823268=$ & 7061.38 & \\
\hline \multicolumn{2}{|c|}{ Published net asset value per share (cents): } & & 7038.00 & p3 \\
\hline
\end{tabular}

It seems to us that you used the unconsolidated number of shares to calculate net asset value per share and market capitalisation. We feel that if the rand amounts for treasury shares are consolidated, then the same consolidation principle should also be applied to the number of shares. In short, we feel that the number of shares used when calculating market capitalisation and net asset value should be the consolidated figure.

We look forward to receiving your response.

Yours sincerely

Names and contact details of authors 


\section{Appendix B}

\begin{tabular}{|c|c|c|c|c|c|c|}
\hline & \multicolumn{3}{|c|}{$\begin{array}{c}\text { Market } \\
\text { capitalisation }\end{array}$} & \multicolumn{3}{|c|}{$\begin{array}{c}\text { Net asset } \\
\text { value }\end{array}$} \\
\hline & 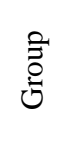 & 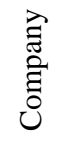 & $\begin{array}{l}\text { है } \\
\text { है } \\
\text { है } \\
5\end{array}$ & $\begin{array}{l}\text { 苛 } \\
\text { 苟 }\end{array}$ & 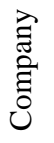 & 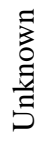 \\
\hline Afrimat Ltd & $\mathrm{X}$ & & & $\mathrm{X}$ & & \\
\hline ArcelorMittal SA Ltd & $\mathrm{X}$ & & & $\mathrm{X}$ & & \\
\hline Brait S.A. & $\mathrm{X}$ & & & $\mathrm{X}$ & & \\
\hline Clicks Group Ltd & $\mathrm{X}$ & & & $\mathrm{X}$ & & \\
\hline Hudaco Industries Ltd & $\mathrm{X}$ & & & $\mathrm{X}$ & & \\
\hline Italtile Ltd & $\mathrm{X}$ & & & $\mathrm{X}$ & & \\
\hline Mercantile Bank Holdings Ltd & $\mathrm{X}$ & & & $\mathrm{X}$ & & \\
\hline Mr Price Group Ltd & $\mathrm{X}$ & & & $\mathrm{X}$ & & \\
\hline Omnia Holdings Ltd & $\mathrm{X}$ & & & $\mathrm{X}$ & & \\
\hline Primeserv Group Ltd & $\mathrm{X}$ & & & $\mathrm{X}$ & & \\
\hline Reunert Ltd & $\mathrm{X}$ & & & $\mathrm{X}$ & & \\
\hline Santam Ltd & $\mathrm{X}$ & & & $\mathrm{X}$ & & \\
\hline Sappi Ltd & $\mathrm{X}$ & & & $\mathrm{X}$ & & \\
\hline Sasfin Holdings Ltd & $\mathrm{X}$ & & & $\mathrm{X}$ & & \\
\hline The Bidvest Group Ltd & $\mathrm{X}$ & & & $\mathrm{X}$ & & \\
\hline Tiger Brands Ltd & $\mathrm{X}$ & & & $\mathrm{X}$ & & \\
\hline Truworths International Ltd & $\mathrm{X}$ & & & $\mathrm{X}$ & & \\
\hline Total: & 17 & & & & & \\
\hline AECI Ltd & & $\mathrm{X}$ & & $\mathrm{X}$ & & \\
\hline African Bank Investments Ltd & & $\mathrm{X}$ & & $\mathrm{X}$ & & \\
\hline Argent Industrial Ltd & & $\mathrm{X}$ & & $\mathrm{X}$ & & \\
\hline $\begin{array}{l}\text { Aspen Pharmacare Holdings } \\
\text { Ltd }\end{array}$ & & $\mathrm{X}$ & & $\mathrm{X}$ & & \\
\hline $\begin{array}{l}\text { Barnard Jacobs Mellet } \\
\text { Holdings Ltd }\end{array}$ & & $\mathrm{X}$ & & $\mathrm{X}$ & & \\
\hline $\begin{array}{l}\text { Brimstone Investment } \\
\text { Corporation Ltd }\end{array}$ & & $\mathrm{X}$ & & $\mathrm{X}$ & & \\
\hline Cadiz Holdings Ltd & & $\mathrm{X}$ & & $\mathrm{X}$ & & \\
\hline $\begin{array}{l}\text { Compu Clearing Outsourcing } \\
\text { Ltd }\end{array}$ & & $\mathrm{X}$ & & $\mathrm{X}$ & & \\
\hline $\begin{array}{l}\text { Distribution and Warehousing } \\
\text { Network Ltd }\end{array}$ & & $\mathrm{X}$ & & $\mathrm{X}$ & & \\
\hline $\begin{array}{l}\text { Erbacon Investment Holdings } \\
\text { Ltd }\end{array}$ & & $\mathrm{X}$ & & $\mathrm{X}$ & & \\
\hline Esorfranki Ltd & & $\mathrm{X}$ & & $\mathrm{X}$ & & \\
\hline Excellerate Holdings Ltd & & $\mathrm{X}$ & & $\mathrm{X}$ & & \\
\hline FirstRand Ltd & & $\mathrm{X}$ & & $\mathrm{X}$ & & \\
\hline Foschini Ltd & & $\mathrm{X}$ & & $\mathrm{X}$ & & \\
\hline Gijima Group Ltd & & $\mathrm{X}$ & & $\mathrm{X}$ & & \\
\hline Group Five Ltd & & $\mathrm{X}$ & & $\mathrm{X}$ & & \\
\hline Imperial Holdings Ltd & & $\mathrm{X}$ & & $\mathrm{X}$ & & \\
\hline Lewis Group Ltd & & $\mathrm{X}$ & & $\mathrm{X}$ & & \\
\hline Mediclinic International Ltd & & $\mathrm{X}$ & & $\mathrm{X}$ & & \\
\hline Nedbank Group Ltd & & $\mathrm{X}$ & & $\mathrm{X}$ & & \\
\hline Netcare Ltd & & $\mathrm{X}$ & & $\mathrm{X}$ & & \\
\hline Oceana Group Ltd & & $\mathrm{X}$ & & $\mathrm{X}$ & & \\
\hline
\end{tabular}

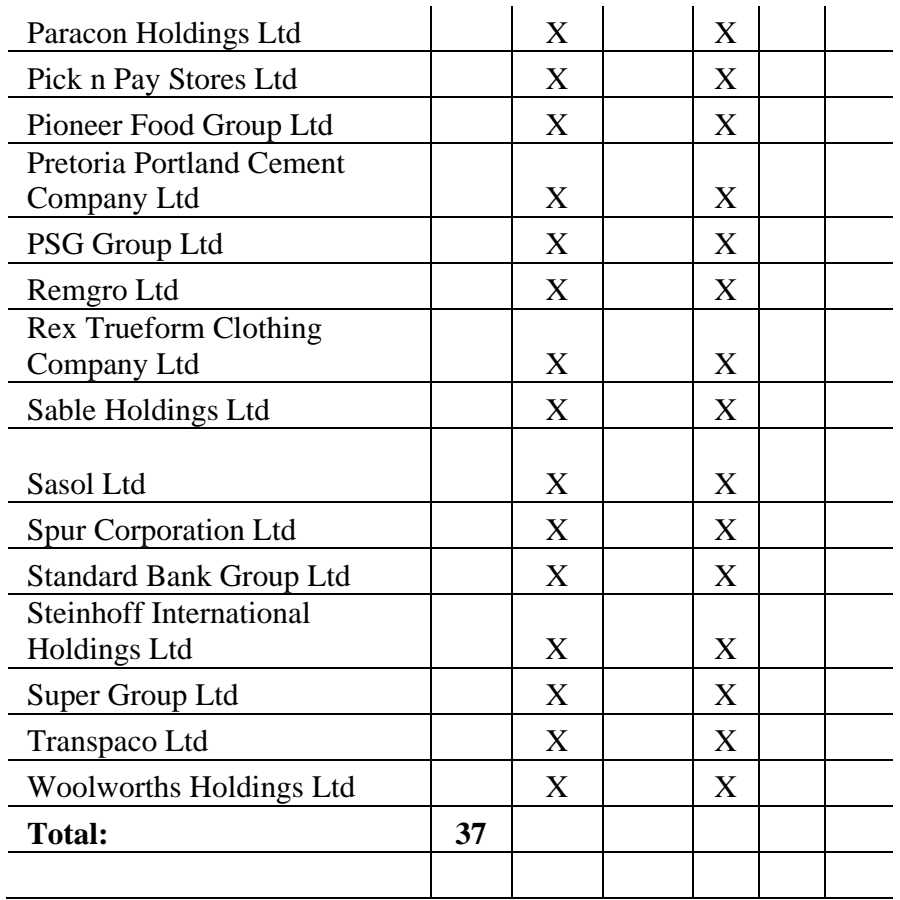

\begin{tabular}{l|c|c|c|c|c|c} 
Absa Group Ltd & & $\mathrm{X}$ & & & $\mathrm{X}$ & \\
\hline Aveng Ltd & & $\mathrm{X}$ & & & $\mathrm{X}$ & \\
\hline Cashbuild Ltd & & $\mathrm{X}$ & & & $\mathrm{X}$ & \\
\hline Datatec Ltd & & $\mathrm{X}$ & & & $\mathrm{X}$ & \\
\hline Distell Group Ltd & & $\mathrm{X}$ & & & $\mathrm{X}$ & \\
\hline Famous Brands Ltd & & $\mathrm{X}$ & & & $\mathrm{X}$ & \\
\hline Massmart Holdings Ltd & & $\mathrm{X}$ & & & $\mathrm{X}$ & \\
\hline Wilson Bayly Holmes-Ovcon Ltd & & $\mathrm{X}$ & & & $\mathrm{X}$ & \\
\hline Total: & $\mathbf{8}$ & & & & & \\
\hline & & & & & & \\
\hline Astrapak Ltd & & $\mathrm{X}$ & & & & $\mathrm{X}$ \\
\hline Barloworld Ltd & & $\mathrm{X}$ & & & & $\mathrm{X}$ \\
\hline Nampak Ltd & & $\mathrm{X}$ & & & & $\mathrm{X}$ \\
\hline & & & & & & \\
\hline $\begin{array}{l}\text { Hosken Consolidated Investment } \\
\text { Ltd }\end{array}$ & & & & & & \\
\hline Nictus Ltd & & & $\mathrm{X}$ & $\mathrm{X}$ & & \\
\hline Winhold Ltd & & & $\mathrm{X}$ & & $\mathrm{X}$ & \\
\hline & & & & & & \\
\hline Sun International Ltd & $\mathrm{XX}$ & & & $\mathrm{X}$ & & \\
\hline & & & & & & \\
\hline $\begin{array}{l}\text { Sentula Mining Ltd } \\
\text { XX - consolidated subsidiary but not the } \\
\text { trust }\end{array}$ & & & & & \\
\hline
\end{tabular}




\section{Appendix C}

\begin{tabular}{|c|c|}
\hline Market capitalisation & $\begin{array}{c}\text { Percentage } \\
\text { increase }\end{array}$ \\
\hline Absa Group Ltd & 0.33 \\
\hline AECI Ltd & 11.08 \\
\hline African Bank Investments Ltd & 0.06 \\
\hline Argent Industrial Ltd & 5.85 \\
\hline Aspen Pharmacare Holdings Ltd & 0.19 \\
\hline Astrapak Ltd & 13.99 \\
\hline Aveng Ltd & 1.54 \\
\hline Barloworld Ltd & 1.91 \\
\hline Barnard Jacobs Mellet Holdings Ltd & 42.81 \\
\hline Brimstone Investment Corporation Ltd & 9.57 \\
\hline Cadiz Holdings Ltd & 12.38 \\
\hline Cashbuild Ltd & 13.63 \\
\hline Compu Clearing Outsourcing Ltd & 1.05 \\
\hline Datatec Ltd & 0.66 \\
\hline Distell Group Ltd & 0.16 \\
\hline Distribution and Warehousing Network Ltd & 11.63 \\
\hline Erbacon Investment Holdings Ltd & 0.54 \\
\hline Esorfranki Ltd & 4.27 \\
\hline Excellerate Holdings Ltd & 6.77 \\
\hline Famous Brands Ltd & 0.05 \\
\hline FirstRand Ltd & 8.14 \\
\hline Foschini Ltd & 15.98 \\
\hline Gijima Group Ltd & 0.69 \\
\hline Group Five Ltd & 26.93 \\
\hline Imperial Holdings Ltd & 12.68 \\
\hline Lewis Group Ltd & 11.66 \\
\hline Massmart Holdings Ltd & 0.68 \\
\hline Mediclinic International Ltd & 5.84 \\
\hline Nampak Ltd & 12.36 \\
\hline Nedbank Group Ltd & 14.44 \\
\hline Netcare Ltd & 12.64 \\
\hline Oceana Group Ltd & 19.46 \\
\hline Paracon Holdings Ltd & 4.18 \\
\hline Pick n Pay Stores Ltd & 7.05 \\
\hline Pioneer Food Group Ltd & 14.02 \\
\hline Pretoria Portland Cement Company Ltd & 11.25 \\
\hline PSG Group Ltd & 12.83 \\
\hline Remgro Ltd & 0.87 \\
\hline Rex Trueform Clothing Company Ltd & 1.66 \\
\hline Sable Holdings Ltd & 8.63 \\
\hline Sasol Ltd & 1.34 \\
\hline Sentula Mining Ltd & 3.31 \\
\hline Spur Corporation Ltd & 11.12 \\
\hline Standard Bank Group Ltd & 5.69 \\
\hline Steinhoff International Holdings Ltd & 6.96 \\
\hline Super Group Ltd & 9.55 \\
\hline Transpaco Ltd & 17.18 \\
\hline Wilson Bayly Holmes-Ovcon Ltd & 20.63 \\
\hline Woolworths Holdings Ltd & 3.41 \\
\hline Average percentage increase: & 8.56 \\
\hline
\end{tabular}

\section{Appendix D}

\begin{tabular}{l|r}
\hline Net asset value & Percentage decrease \\
\hline & \\
\hline Absa Group Ltd & 0.33 \\
\hline Aveng Ltd & 1.52 \\
\hline Cashbuild Ltd & 12.00 \\
\hline Datatec Ltd & 0.66 \\
\hline Distell Group Ltd & 0.16 \\
\hline Famous Brands Ltd & 0.05 \\
\hline Massmart Holdings Ltd & 0.68 \\
\hline Wilson Bayly Holmes-Ovcon Ltd & 17.10 \\
\hline Winhold Ltd & 0.56 \\
\hline & \\
\hline Average percentage decrease: & 3.67 \\
\hline
\end{tabular}

Author's Note

This material is based upon work supported financially by the National Research Foundation (NRF). However, the NRF does not accept responsibility for any opinions, findings, conclusions or recommendations expressed by the authors of this study. 